\title{
C2G Online Trust, Perceived Government Responsiveness and User Experience
}

\section{A Pilot Survey in St. Petersburg, Russia}

\author{
Yury Kabanov $^{1,2}$ and Lyudmila Vidiasova ${ }^{1}$ \\ ${ }^{1}$ ITMO University, St. Petersburg, Russia \\ ${ }^{2}$ National Research University Higher School of Economics, St. Petersburg, Russia \\ ykabanov@hse.ru, bershadskaya.lyudmila@gmail.com
}

\begin{abstract}
The paper presents the results of the pilot study of $C 2 G$ online trust, that covers citizens' trust in communication with the government via egovernment, e-participation and social media channels. Based on the survey carried out in St. Petersburg, we explore dimensions of $C 2 G$ trust and test the impact of perceived government responsiveness, user experience and sociodemographic factors in shaping trust. Our findings suggest that both perceived responsiveness and user experience influence the level of trust, while age, gender and education are not significant when controlled to the frequency of Internet use. The research proposes to consider to view $C 2 G$ trust as a multidimensional phenomenon, as its dynamics may vary across the tools and sectors used. Implications for future research are given.
\end{abstract}

Keywords: Trust, Online Trust, E-Government, E-Participation, Perceived Government Responsiveness, User Experience

\section{Introduction}

Despite the growing volume of research, the question of how to make effective citizen-government (C2G) communication online remains open [39]. Among the numerous prerequisites for making e-government and e-participation meaningful, there is the multifaceted concept of trust [34], which, however, poses a challenge for its holistic evaluation and practical development. In this paper, we aim at contributing to the research on $C 2 G$ online trust, i.e. a person's trust in communicating with public officials via e-government, e-participation or the social media. We present pilot results of the project exploring this phenomenon and factors that impact its dynamics, focusing on St. Petersburg, Russia. It is a new empirical case for online trust and ICT adoption studies, which are often centered on the US, Europe, Asia or the Middle East [40]. In this paper we explore the peculiarities of $C 2 G$ online trust in a large Russian city, as well as test the impact of user experience, perceived government responsiveness and socio-demographic characteristics on trust. We analyze the data we obtained from the pilot opinion survey (600 respondents), carried out in St. Petersburg in 2018. 
The paper is structured as follows. Firstly, we briefly outline the state-of-the-art in online trust research in relation to e-government / e-participation. Secondly, we describe the methodology of research and overview the data. In the third part we present the findings, followed by discussion of the results, limitations and future steps.

\section{C2G Online Trust: State of the Art}

Due to the multifaceted nature of trust, it is important to outline, at least roughly, the key directions of its research in relation to e-government (e-participation). For this purpose we apply scientometrics approach: using VOSviewer software [38], we have created a keyword co-occurrence map (the intensity of keywords occurring together in a single item) from 823 articles, indexed in the Web of Science database, retrieved by the search query: $T S=($ trust $) A N D T S=(e$-government $O R$ e-participation OR egovernment OR eparticipation). For the analysis we have selected 98 keywords that occur at least 10 times in the sample, excluding the query terms, as they may be found in practically all samples and skew the analysis. The minimum threshold for cluster formation is 5 terms (attraction - "2", repulsion - “0”).

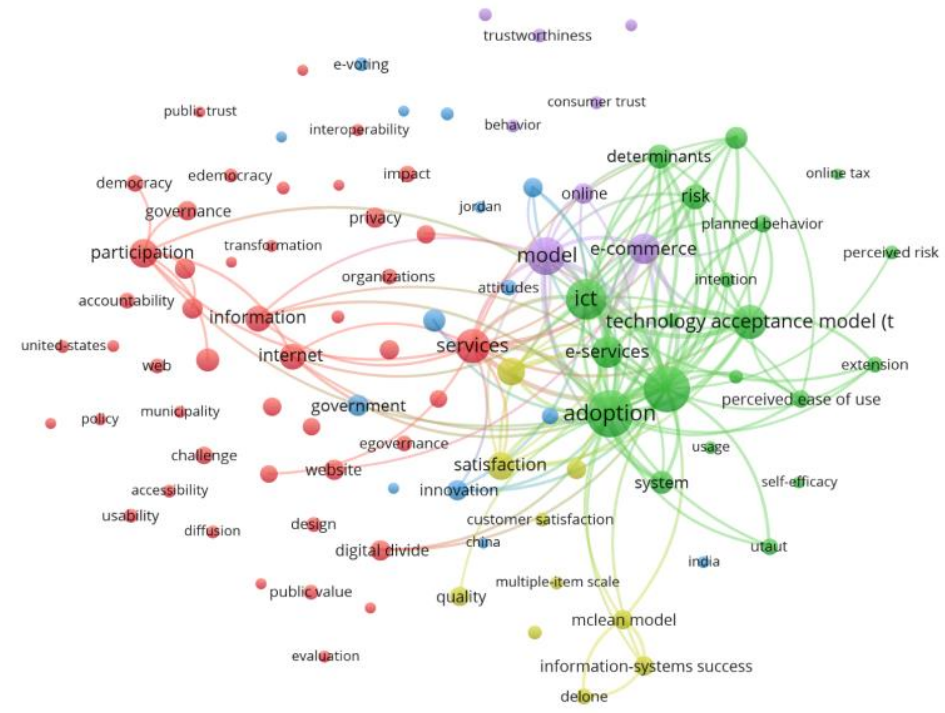

Fig. 1. Keyword Co-Occurrence Map of Trust in E-Government / E-Participation Research. Source: VOSviewer (http://vosviewer.com)

In the visualization (fig. 1) the size of items depicts its occurrences, while the lines show the links strength between items. We may see that the research area is divided into several interconnected research contexts. Methodologically, the literature on trust in e-government (e-participation) seems to be dominated by several theoretical models. The first one (the green cluster) is the technology acceptance model [7] with its modifications and variables (perceived ease of use, risk and usefulness), with a topical focus on e-services and a close connection to e-commerce (the purple cluster). The 
yellow cluster focuses on the interaction between trust and user satisfaction issues, based mostly on the information systems success model that takes into account quality of systems and information [14; 30]. In this segment (the green, purple and yellow clusters) trust is mostly used as a dependent or moderating variable that impacts the intentions of ICT users, especially in relation to public and commercial services. On the contrary, the blue and red clusters are less internally coherent, with less occurring concepts and fewer strong connections. They seem to represent the research on how trust, e-tools use and government performance reinforce each other, and deals with such issues as transparency, responsiveness and accountability [21; 36]. It also touches such dimensions of $\mathrm{C} 2 \mathrm{G}$ interaction as e-democracy, e-governance, e-voting, open government and social media. The visualization reveals further that trust is a multifaceted concept, with different dimensions being considered by different research foci. Thus, while the red and blue clusters tend to analyze political and institutional trust, others deal with more personal facets (e.g. consumer and interpersonal trust).

Despite a lot of research, there are several challenges in the empirical study of trust, which are complicated by the multidisciplinary nature of the phenomenon [4]. The first problem occurs in defining and operationalizing the concept: what kind of trust actually matters for adoption and use of new technologies? Although trust in government and trust in the Internet (technology) are the usual suspects [8;11;40], there is no single answer if both are equally important $[9 ; 18]$, or whether there is a reversed causal link between e-government use and trust formation [29]. Some scholars studied another important dimension of trust, i.e. trust in e-government, as well as trust in e-participation, which is explored less [33]. It is not necessarily a covariate of trust in government or technology [18], and can be viewed as a complex phenomenon on its own right, as proposed for e-government [28], or e-participation [31].

Exploring the predictors of trust in e-government or e-participation is the second challenging issue. So far various factors have proven their significance, like technology acceptance model variables [1;24;34], user satisfaction [20] quality of information and services [22], trust in technology or government [4] etc. Recently sociodemographic characteristics - age, gender, education level - have drawn the attention of the academia [3;5]. While the research on trust determinants seems fruitful, the findings are usually based on opinion surveys and thus need to be verified in other contexts. Moreover, it is hard to combine all factors in a general fit-all-model.

Finally, the interpretation of results are usually affected by the difficulty to set a single causal link. As there is no single unified theory, depending on model specifications, trust, user satisfaction, ICT usage etc. are utilized as both dependent and independent variables [26]. And even more, it seems intuitive, because, as Scherer and Wimmer put it, trust is at the same time a condition and an outcome of e-participation, as well as enshrined into the very process of it [33].

In sum, despite a substantial progress, research gaps remain, and still work is needed in both new empirical research and theoretical conceptualization of trust in egovernment and e-participation contexts. 


\section{$3 \quad$ Research Design}

Dependent Variable. In our definition of trust we concentrate on trust in communication with the government online, i.e. whether a citizen considers interaction with public authorities on the Internet trustworthy. It is a certain reduction and simplification of the previous elaborate models [28; 34]. But on the other hand, we believe such communication trust is the essence that underpin successful e-projects, while other elements are either its predictors or outcomes. At the same time, by using the term $C 2 G$ online trust - we hope to synthesize previous studies on trust in e-government and e-participation. This is due to the fact that both have become complex, in many respects, intertwined systems of different tools. Moreover, new dimensions should count, like social media, which, is another domain of $\mathrm{C} 2 \mathrm{G}$ interaction that may involve trust relations [2].

In this regards, $C 2 G$ online trust needs to be taken as a related but conceptually distinct phenomenon from both trust in government and in technologies. Such an approach is based on previous studies of trust in e-government [18], as well as on the assumption that offline perceptions, attitudes and activities may have different dynamics than their online manifestations, for instance, in cases of political participation [17] and efficacy [32], close correlates of trust. At the same time, C2G online trust is not a single attitude and does not equate to online trust in general, since the latter, as found by Constante et. al [12], might have different dynamics across domains (ecommerce, e-health etc.) and particular websites. Hence, we might argue such trust is a multidimensional resultant of a person's encounter (or non-use) and attitudes to various e-government (e-participation, the social media) tools.

Thus, we measure the level of trust asking people whether they trust ICTs (the Internet, mobile technologies etc.) in the following situations: (1) getting e-services; (2) e-complaints submission; (3) e-petitions submission; (4) voting for e-petitions; (5) communication with the government via social media. The 4-point Likert scale was used to assess their level of trust to each: from "fully trust" to "don't trust".

Independent Variables. The pilot study is limited, making it impossible to test all promising hypotheses. We focus on three aspects, which also have visible practical applications: user experience, perceived government responsiveness, and sociodemographic characteristics.

User experience is usually analyzed in the context of user satisfaction or skillfulness [5;19]. However, in this paper we mostly deal with the actual exposure to e-tools, with the goal to contribute to the literature on different perceptions of new technologies by users and non-users [27;37]. Again, we take a multidimensional approach, following Distel that "nonadoption may not affect all available e-government services but only selected services" [15, p. 99]. Thus we ask citizens whether they have experience in using the selected e-tools in Russia: e-service portal (gosuslugi.ru), city ecomplaint portal "Our Petersburg", federal e-petitions portal "Russian Public Initiative" and submitting e-complaints or appeals (via e-mails, special website forms etc.).

Perceived government responsiveness is another usual suspect that moderates trust and online interaction with the government $[21 ; 23 ; 25 ; 35 ; 36]$. Its meaning is close to the external political efficacy - the feeling citizens can actually influence the govern- 
ment [13], but unlike the latter, is related to more specific actions of decision-makers, the evaluation of the government as acting in accordance with public demands [16]. We ask citizens to what extent they agree that the development of the Internet makes public agencies more attentive to public complaints, more responsive to citizens and focused on citizens' problems.

The final set of variables are used to address the research gap with understanding sociodemographic dimensions of trust, in particular gender, age and education level, a promising but underexplored area that needs other empirical evidence $[3 ; 4 ; 5]$. The list of variables and its operationalization in the survey and the statistical analysis is presented in Table 1. In general, our hypotheses are that higher level of trust in G2C communication online is positively defined by the (1) citizens' experience of using the tools; (2) higher levels of perceived government responsiveness; (3) younger age; (4) higher level of education and (5) gender characteristics, when controlled by the level of the Internet use.

Table 1. Operationalization of the Concepts

\begin{tabular}{|c|c|c|c|}
\hline Concept & Variable & Question & Answers / Coding \\
\hline 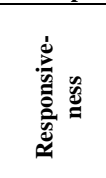 & $\begin{array}{l}\text { Perceived Government Respon- } \\
\text { siveness }\end{array}$ & $\begin{array}{l}\text { Do you agree with the statement } \\
\text { "As the Internet use increases, } \\
\text { government bodies pay more } \\
\text { attention to citizens" demands } \\
\text { (become more responsive, atten- } \\
\text { tive to citizens)" }\end{array}$ & $\begin{array}{l}4 \text { - Fully agree } \\
\text { 3-Somewhat agree } \\
\text { 2-Somewhat disagree } \\
\text { 1-Fully disagree }\end{array}$ \\
\hline \multirow{5}{*}{ 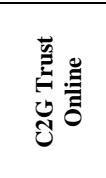 } & in e-services & \multirow{5}{*}{$\begin{array}{l}\text { Do you trust ICTs as a communi- } \\
\text { cation tool in the following cases } \\
\text { (e-services acquisition, } \\
\text { complaints submission..)? }\end{array}$} & \multirow{5}{*}{$\begin{array}{l}\text { 4-Yes, fully trust } \\
\text { 3-Somewhat yes } \\
\text { 2-Somewhat no } \\
\text { 1-No }\end{array}$} \\
\hline & in e-complaints and appeals & & \\
\hline & in e-petition submission & & \\
\hline & in voting for e-petitions & & \\
\hline & $\begin{array}{l}\text { in } \mathrm{G} 2 \mathrm{C} \text { communication in the } \\
\text { social media }\end{array}$ & & \\
\hline \multirow{4}{*}{ 䓂 } & $\begin{array}{l}\text { of the federal e-service por- } \\
\text { tal usage (gosuslugi.ru) }\end{array}$ & \multirow{4}{*}{$\begin{array}{l}\text { Do you have a personal experience } \\
\text { in: submitting an e-complaint, } \\
\text { usage of the federal e-service } \\
\text { portal... }\end{array}$} & \multirow{4}{*}{$\begin{array}{l}\text { 4-Yes, and it is a positive } \\
\text { experience } \\
3 \text {-Yes, and it is a negative } \\
\text { experience } \\
\text { 2-No, but I want to try } \\
1 \text {-No, and I do not want to try }\end{array}$} \\
\hline & $\begin{array}{l}\text { of the regional Our Petersburg } \\
\text { portal usage }\end{array}$ & & \\
\hline & $\begin{array}{l}\text { of the federal e-petition portal } \\
\text { RPI usage }\end{array}$ & & \\
\hline & $\begin{array}{l}\text { of submitting e-complaints and } \\
\text { appeals to public authorities }\end{array}$ & & \\
\hline \multirow{4}{*}{ 竎总 } & Internet use frequency & \multicolumn{2}{|c|}{$\begin{array}{l}\text { 5-Almost always online; 4-Every day; 3-Several times a week; 2- } \\
\text { Several times a month;1- Never }\end{array}$} \\
\hline & Age & \multicolumn{2}{|c|}{$\begin{array}{l}6-18-25 \text { years old; } 5-26-35 ; 4-36-45 ; 3-46-55 ; 2-56-65 ; 1- \\
\text { over } 65 \text { years old }\end{array}$} \\
\hline & Gender & \multicolumn{2}{|c|}{1 - male; 0 - female } \\
\hline & Education & \multicolumn{2}{|c|}{3 - University; 2 - College; 1 - High School } \\
\hline
\end{tabular}

Data \& Methods. The data we use come from the public opinion survey held in November 2018 in St. Petersburg. The sample contains 600 responses from visitors, randomly asked questions (Table 1) at six multi-functional centers that provide state and municipal services for citizens. The sample calculated is representative on the size, age and gender, the sampling error does not exceed 4 per cent. Respondents were profiled by the level of the Internet use, age, gender and occupation. Overall there are $43 \%$ of men and $57 \%$ of women in the sample. The majority of the respondents are employees / specialists (39\%), workers/guards/drivers (20\%) and students (10\%). To 
test the hypothesis we use several statistical methods. First, we run the exploratory correlation analysis (Kendall's tau) to find associations between the variables. Secondly, we use factor analysis to study dimensions of trust and reduce them into a single scale variable, which is used as an independent variable in the linear regression.

\section{Empirical Analysis}

Exploratory Correlation Analysis. The survey confirms that $C 2 G$ online trust is indeed a multidimensional phenomenon, as the level of trust varies across channels.

Table 2. Results of the Correlation Analysis

\begin{tabular}{|c|c|c|c|c|c|}
\hline & $\begin{array}{c}\text { Trust } \\
\text { (E-Services) }\end{array}$ & $\begin{array}{c}\text { Trust } \\
\text { (E- } \\
\text { Complaints } \\
\text { \& Appeals) }\end{array}$ & $\begin{array}{c}\text { Trust } \\
\text { (E-Petition } \\
\text { Submission) }\end{array}$ & $\begin{array}{l}\text { Trust } \\
\text { (E-Petition } \\
\text { Voting) }\end{array}$ & $\begin{array}{c}\text { Trust } \\
\text { (Social Media) }\end{array}$ \\
\hline Trust (E-Services) & & $\begin{array}{c}, 734^{* *} \\
(600)\end{array}$ & $\begin{array}{c}, 670 * * \\
(600)\end{array}$ & $\begin{array}{c}, 581 * * \\
(600)\end{array}$ & $\begin{array}{c}, 549 * * \\
(600)\end{array}$ \\
\hline $\begin{array}{c}\text { Trust (E- } \\
\text { Complaints \& Appeals) }\end{array}$ & $\begin{array}{l}, 734 * * \\
(600)\end{array}$ & & $\begin{array}{l}(812 * * \\
(600)\end{array}$ & $\begin{array}{l}, 727 * * \\
(600)\end{array}$ & $\begin{array}{l}, 519 * * \\
(600)\end{array}$ \\
\hline $\begin{array}{l}\text { Trust (E-Petition } \\
\text { Submission) }\end{array}$ & $\begin{array}{l}670 * * \\
(600)\end{array}$ & $\begin{array}{l}, 812 * * \\
(600)\end{array}$ & & $\begin{array}{l}8857 * * \\
(600)\end{array}$ & $\begin{array}{l}551 * * \\
(600)\end{array}$ \\
\hline $\begin{array}{l}\text { Trust (E-Petition } \\
\text { Voting) }\end{array}$ & $\begin{array}{l}, 581 * * \\
(600)\end{array}$ & $\begin{array}{l}, 727 * * \\
(600)\end{array}$ & $\begin{array}{l}857 * * \\
(600)\end{array}$ & & $\begin{array}{l}527 * * \\
(600)\end{array}$ \\
\hline $\begin{array}{l}\text { Trust (Social Me- } \\
\text { dia) }\end{array}$ & $\begin{array}{l}549 * * \\
(600)\end{array}$ & $\begin{array}{l}519 * * \\
(600)\end{array}$ & $\begin{array}{l}.551 * * \\
(600)\end{array}$ & $\begin{array}{l}.527 * * \\
(600)\end{array}$ & \\
\hline $\begin{array}{c}\text { Perceived Gov- } \\
\text { ernment Responsive- } \\
\text { ness } \\
\end{array}$ & $\begin{array}{l}, 446 * * \\
(600)\end{array}$ & $\begin{array}{l}382 * * \\
(600)\end{array}$ & $\begin{array}{l}454 * * \\
(600)\end{array}$ & $\begin{array}{l}, 429 * * \\
(600)\end{array}$ & $\begin{array}{l}, 399 * * \\
(600)\end{array}$ \\
\hline $\begin{array}{c}\text { Experience of E- } \\
\text { Services (Gosuslugi.ru) }\end{array}$ & $\begin{array}{l}430 * * \\
(562)\end{array}$ & $\begin{array}{l}388 * * \\
(562)\end{array}$ & $\begin{array}{l}369 * * \\
(562)\end{array}$ & $\begin{array}{l}320 * * \\
(562)\end{array}$ & $\begin{array}{l}, 324 * * \\
(562)\end{array}$ \\
\hline $\begin{array}{c}\text { Experience of the } \\
\text { Our Petersburg portal }\end{array}$ & $\begin{array}{l}162 * * \\
(528)\end{array}$ & $\begin{array}{l}128 * * \\
(528)\end{array}$ & $\begin{array}{l}132 * * \\
(528)\end{array}$ & $\begin{array}{l}119 * * \\
(528)\end{array}$ & $\begin{array}{l}0088^{*} \\
(528)\end{array}$ \\
\hline $\begin{array}{l}\text { Experience of the } \\
\text { Russian Public Initia- } \\
\text { tive portal }\end{array}$ & $\begin{array}{c}, 122 * * \\
(509)\end{array}$ & $\begin{array}{l}, 047 \\
(509)\end{array}$ & $\begin{array}{c}, 071 \\
(509)\end{array}$ & $\begin{array}{l}, 059 \\
(509)\end{array}$ & $\begin{array}{l}, 032 \\
(509)\end{array}$ \\
\hline $\begin{array}{c}\text { Experience of E- } \\
\text { Complaints Submission }\end{array}$ & $\begin{array}{l}307 * * \\
(505)\end{array}$ & $\begin{array}{l}374 * * \\
(505)\end{array}$ & $\begin{array}{l}348 * * \\
(505)\end{array}$ & $\begin{array}{l}276^{* * *} \\
(505)\end{array}$ & $\begin{array}{l}273^{* *} \\
(505)\end{array}$ \\
\hline Gender & $\begin{array}{l}, 096^{*} \\
(600)\end{array}$ & $\begin{array}{l}104 * * \\
(600)\end{array}$ & $\begin{array}{l}, 079^{*} \\
(600)\end{array}$ & $\begin{array}{l}090^{*} \\
(600)\end{array}$ & $\begin{array}{l}05 \\
(600) \\
, 055 \\
\end{array}$ \\
\hline Age & $\begin{array}{l}, 327 * * \\
(600)\end{array}$ & $\begin{array}{l}429 * * \\
(600)\end{array}$ & $\begin{array}{l}378^{* *} \\
(600)\end{array}$ & $\begin{array}{l}, 313 * * \\
(600)\end{array}$ & $\begin{array}{l}, 223^{* *} \\
(600)\end{array}$ \\
\hline Level of Education & $\begin{array}{l}, 385 * * \\
(600)\end{array}$ & $\begin{array}{l}373 * * \\
(600)\end{array}$ & $\begin{array}{l}, 348 * * \\
(600)\end{array}$ & $\begin{array}{l}333^{* * *} \\
(600)\end{array}$ & $\begin{array}{l}, 263^{* *} \\
(600)\end{array}$ \\
\hline $\begin{array}{l}\text { Frequency of the } \\
\text { Internet Use }\end{array}$ & $\begin{array}{l}509 * * \\
(593)\end{array}$ & $\begin{array}{l}, 575^{* *} \\
(593)\end{array}$ & $\begin{array}{l}524 * * \\
(593)\end{array}$ & $\begin{array}{c}467 * * * \\
(593)\end{array}$ & $\begin{array}{l}359^{* *} \\
(593)\end{array}$ \\
\hline
\end{tabular}

In the correlation analysis (Table 2): while all dimensions of $G 2 C$ online trust correlate positively and significantly with each other, the strength of association differs. Trust in e-services has the strongest correlation with trust in e-complaints, and trust in communication via social media is related closer to submitting e-petitions, thus form- 
ing two profiles of more formal and informal (or managerial and political) communication with public institutions. Although nothing can be said about causation at this point, most of our independent variables correlate positively with trust levels. For instance, perceived government responsiveness seems a promising predictor of trust. It presents rather similar significance across the sectors. The situation is more complicated with the user experience. On the one hand, at large, users tend to trust more than non-users, and indeed, exposure to particular channels in some cases correlates more strongly with trust to specific forms of communication (e-services, e-complaints and appeals). At the same time, experience of the Russian Public Initiative portal does not correlate with trust in e-petitioning, maybe due to the low level of its usage and efficacy [10].

Socio-demographic characteristics correlate significantly as well. Younger, more educated people and frequent Internet-users trust all online channels more. The weakest association here is with social media mechanisms, i.e. distrust in this channel is more or less equal among different social groups. While gender proves to be important is some cases (male respondents trust more in submitting e-complaints), other correlations are not so significant. It is important to note that previous studies in Saudi Arabia have shown reverse results [5], which proves that the context does matter.

Regression Analysis. Preliminary correlation analysis helps to identify the most promising predictors for the regression model. Before running the linear regression analysis, a single independent variable $-C 2 G$ online trust - was calculated out of the measured dimensions. This was done by the factor analysis (principal component method), to reveal a possible latent factor that drives all of the dimensions. Based on the predefined settings of extraction (eigenvalues over 1), only one component was revealed that explains about 77 percent of the variance. The component matrix (Table 3) shows substantially high loadings of all variables on the factor, and the extracted factor correlates highly and significantly with all the variables (Table 4). Although some of the data inevitably disappear during the procedure, it seems nevertheless justified to use the factor as a single scale independent variable.

The regression analysis (OLS) was carried out to identify the model that best suits the data. All models presented are checked on the basic assumptions of the lack of multicollinearity, autocorrelation and heteroscedasticity. We compare models and variables based on the standardized beta-coefficients of predictors, as well as take into account the percentage of explained variance (adjusted R-square) and the level of standardized error. The selected models are presented in Table 5.

Table 3. Component Matrix - C2G Online Trust

\begin{tabular}{ccccc}
\hline \multicolumn{5}{c}{ Trust in... } \\
\hline E-Services & E-Complaints \& Appeals & $\begin{array}{c}\text { E-Petition Sub- } \\
\text { mission }\end{array}$ & $\begin{array}{c}\text { E-Petition } \\
\text { Voting }\end{array}$ & Social Media \\
\hline, $\mathbf{8 6 2}$ & $\mathbf{9 2 1}$ & $\mathbf{9 4 1}$ & $\mathbf{8 9 9}$ & $\mathbf{7 5 8}$ \\
\hline
\end{tabular}


Table 4. Results of the Correlation Analysis (Kendall's tau)

\begin{tabular}{|c|c|c|c|c|c|}
\hline & $\begin{array}{c}\begin{array}{c}\text { Trust } \\
\text { (E- } \\
\text { Services) }\end{array} \\
\end{array}$ & $\begin{array}{c}\text { Trust } \\
\text { (E- } \\
\text { Complaints } \\
\text { \& Appeals) }\end{array}$ & $\begin{array}{c}\text { Trust } \\
\text { (E-Petition } \\
\text { Submission) }\end{array}$ & $\begin{array}{c}\text { Trust } \\
\text { (E-Petition } \\
\text { Voting) }\end{array}$ & $\begin{array}{c}\text { Trust } \\
\text { (Social Me- } \\
\text { dia) }\end{array}$ \\
\hline $\begin{array}{c}\text { C2G Online } \\
\text { Trust }\end{array}$ & $\begin{array}{c}726 * * \\
(600)\end{array}$ & $\begin{array}{c}803 * * \\
(600)\end{array}$ & $\begin{array}{c}844 * * \\
(600)\end{array}$ & $\begin{array}{c}792 * * \\
(600)\end{array}$ & $\begin{array}{c}638 * * \\
(600)\end{array}$ \\
\hline
\end{tabular}

Table 5. Regression Models (Dependent Variable - C2G Online Trust)

\begin{tabular}{|c|c|c|c|c|c|c|}
\hline \multirow[t]{2}{*}{ Predictors } & \multicolumn{6}{|c|}{ Standardized Beta - Coefficients } \\
\hline & Model 1 & Model 2 & Model 3 & Model 4 & Model 5 & Model 6 \\
\hline $\begin{array}{l}\text { Perceived Respon- } \\
\text { siveness }\end{array}$ &, $280 * *$ &, $277 * *$ &, $292 * *$ &, $290 * *$ &, $289 * *$ &, $315^{* * *}$ \\
\hline $\begin{array}{l}\text { Experience of E- } \\
\text { Services }\end{array}$ & ,057 & ,034 & - & - & - &, $161 * *$ \\
\hline $\begin{array}{l}\text { Experience of the } \\
\text { Our Petersburg } \\
\text { portal }\end{array}$ & ,008 & - & - & - & - & ,018 \\
\hline $\begin{array}{l}\text { Experience of the } \\
\text { RPI portal }\end{array}$ &,- 074 & - & - & - & - &,- 080 \\
\hline $\begin{array}{l}\text { Experience of E- } \\
\text { Complaints }\end{array}$ &, $102 * *$ &, $101 * *$ & $116^{* *}$ &, $111 * *$ &, $121 * *$ &, $164 * *$ \\
\hline Gender &,- 010 & ,000 & - & - & - &, 008 \\
\hline Age & ,066 & 061 & ,065 & - & - &, $280 * *$ \\
\hline Education & ,081 &, 069 & ,089 & 0,88 & - &, $179 * *$ \\
\hline Internet Use &, $453 * *$ &, $467 * *$ &, $451 * *$ &, $497 * *$ &, $540 * *$ & - \\
\hline Adj. R-Square &, 581 &, 574 &, 563 &, 562 &, 557 &, 521 \\
\hline Std. Error & ,634 & ,631 &, 640 &, 640 & ,644 & 684 \\
\hline
\end{tabular}

The first finding is that the level of perceived government responsiveness remains a significant predictor of $C 2 G$ online trust throughout all models and when controlled for other variables. Thus we may confirm the hypothesis that more positive views of government responsiveness positively influence the trustworthiness of $\mathrm{C} 2 \mathrm{G}$ communications on the Internet from the citizens' viewpoint.

In the case of the user experience the results are more modest. Only experience in submitting e-complaints is significant when controlled for other factors, and the coefficient is not very high. It may be explained statistically, due to a relatively higher loading of trust in e-complaints in the final variable (Table 3), which makes it more connected to this particular experience. Also, a strong correlation between different experiences makes it problematic to use them in one model. Current results suggest partial confirmation of the hypothesis with the need of further testing.

While gender is not significant in all the models, age and education level can be considered relevant predictors, only when they are not controlled for the Internet use frequency (Model 6) and lose their significance in other models. In other words, while a more frequent use of the Internet is indeed expected from younger or more educated people, the former influences the level of trust more strongly. Thus the hypotheses related to these factors are rather rejected.

Overall, the best model we have found for the data is Model 5, which includes perceived government responsiveness, user experience in e-complaints and the frequency of Internet use. It explains about 56 percent of the variance. While this is a good result, more research is to be done to build a more comprehensive model. 


\section{Discussion}

This pilot study is a starting point of the project, but its results may already contribute to the existing research. First of all, it presents a new empirical case, so far underexplored in the studies of online trust. Though the survey was carried out in one city and cannot be extrapolated to the whole country, the findings may be used to compare, how different national (regional) contexts moderate predictors of trust to $\mathrm{C} 2 \mathrm{G}$ online communications. Secondly, our findings confirm the necessity to consider $C 2 G$ online trust as a broad multidimensional concept that broadens and synthesizes the phenomena of trust in e-government and e-participation [28; 34], involves new issues like new media [2], and is a resultant of trust in communication with the government via different channels. Thirdly, we have tested the importance of perceived government responsiveness, different dynamics of user experience, and sociodemographic characteristics, thus providing new empirical evidence to these areas of inquiry. Finally, our scientometrics analysis can also be of use for further research on trust is e-government or e-participation contexts.

Of course, there are several limitations as well. Due to the survey-based statistical analysis, the findings are context-dependent and need to be contrasted against similar studies (e.g. [5]). The number of questions asked in the pilot survey was also limited, hence some possibly important items were not included. Limitations of the statistical analysis should also be considered, as the use of the Likert-scale and dummy variables cause complications in interpretation and leads to simplification of the models.

Finally, as most papers in the area, there is a problem of establishing causalities. This research deals with it empirically, assuming that user experience and prior feedback from the government influence the level of trust at the moment of survey. At the same time, we admit the link can go the other direction, which makes it necessary to continue developing a suitable theoretical model.

\section{Conclusion}

The research reiterates the importance of studying trust in relation to online communication with the government, exploring its dimensions and predictors. Several perspectives of further research can be discerned. Firstly, it is important to consider other dimensions of online trust (e.g. in e-commerce, e-health, e-education), institutional and interpersonal trust, and how they may relate or shape citizens' perceptions towards the government. Secondly, the presented models can be expanded in terms of new independent variables - user satisfaction, perceptions of security, depositions to trust - and specification of the models to particular sectors of e-government, eparticipation and the social media. Thirdly, a new theoretical underpinning is to be developed, for better conceptualization of the findings. Most of these steps are planned in the forthcoming survey of 2019. 


\section{$7 \quad$ Acknowledgements}

The study was performed with financial support by the grant from the Russian Foundation for Basic Research (project №18-311-20001): "The research of cybersocial trust in the context of the use and refusal of information technology".

\section{References}

1. Abu-Shanab, E.: Antecedents of trust in e-government services: an empirical test in Jordan. Transforming Government: People, Process and Policy. 8 (4), 480 - 499 (2014). doi: 10.1108/TG-08-2013-0027

2. Alarabiat, A., Soares, D. S., \& Estevez, E.: Predicting citizens acceptance of governmentled e-participation initiatives through social Media: a theoretical model. In: Proceedings of the Hawaii International Conference on System Sciences (2017). doi: 10.24251/HICSS.2017.345

3. Albesher, A. et al.: The Effects of Individual Differences on Trust in e-Government Services: an Empirical Evaluation. In: Janssen, M., Bannister, F., Glassey, O., Scholl, H., Tambouris, E., Wimmer, M. and Macintosh, A. (eds.), Electronic Government and Electronic Participation, pp. 120-129, IOS Press (2014)

4. Alzahrani, L., Al-Karaghouli, W., \& Weerakkody, V.: Analysing the critical factors influencing trust in e-government adoption from citizens' perspective: A systematic review and a conceptual framework. International business review. 26 (1), 164-175 (2017). doi: 10.1016/j.ibusrev.2016.06.004

5. Alzahrani, L., Al-Karaghouli, W., \& Weerakkody, V.: Investigating the impact of citizens' trust toward the successful adoption of e-government: A multigroup analysis of gender, age, and internet experience. Information Systems Management, 35(2), 124-146 (2018). doi: 10.1080/10580530.2018.1440730

6. Bart, Y., Shankar, V., Sultan, F., \& Urban, G. L.: Are the drivers and role of online trust the same for all web sites and consumers? A large-scale exploratory empirical study. Journal of marketing, 69(4), 133-152 (2005). doi: 10.1509/jmkg.2005.69.4.133

7. Belanche, D., Casaló, L. V., \& Flavián, C.: Integrating trust and personal values into the Technology Acceptance Model: The case of e-government services adoption. Cuadernos de Economía y Dirección de la Empresa, 15(4), 192-204 (2012). doi: 10.1016/j.cede.2012.04.004

8. Carter, L., \& Bélanger, F.: The utilization of e-government services: citizen trust, innovation and acceptance factors. Information systems journal, 15(1), 5-25 (2005). doi: 10.1111/j.1365-2575.2005.00183.x

9. Carter, L., Weerakkody, V., Phillips, B., \& Dwivedi, Y. K.: Citizen adoption of egovernment services: Exploring citizen perceptions of online services in the United States and United Kingdom. Information Systems Management, 33(2), 124-140 (2016). doi: 10.1080/10580530.2016.1155948

10. Chugunov, A.V., Kabanov, Y., Zenchenkova, K.: Russian e-petitions portal: exploring regional variance in use. In: Tambouris, E., et al. (eds.) ePart 2016. LNCS, vol. 9821, pp. 109-122. Springer, Cham (2016). doi: 10.1007/978-3-319-45074-2_9

11. Colesca, S. E.: Understanding trust in e-government. Engineering Economics, 63(4), 1-9 (2009). URL: http://www.inzeko.ktu.lt/index.php/EE/article/view/11637 
12. Costante, E., Den Hartog, J., \& Petkovic, M.: On-line trust perception: What really matters. In: 2011 1st Workshop on Socio-Technical Aspects in Security and Trust (STAST), pp. 52-59, IEEE (2011). doi: 10.1109/STAST.2011.6059256

13. Craig, S. C., Niemi, R. G., \& Silver, G. E.: Political efficacy and trust: A report on the NES pilot study items. Political behavior, 12(3), 289-314 (1990). doi: 10.1007/BF00992337

14. Delone, W. H., \& McLean, E. R.: The DeLone and McLean model of information systems success: a ten-year update. Journal of management information systems, 19(4), 9-30 (2003). doi: 10.1.1.88.3031

15. Distel, B.: Bringing Light into the Shadows: A Qualitative Interview Study on Citizens' Non-Adoption of e-Government. Electronic Journal of e-Government, 16(2), 98-105 (2018).

16. Esaiasson, P., Kölln, A. K., \& Turper, S.: External efficacy and perceived responsiveness-Similar but distinct concepts. International journal of public opinion research, 27(3), 432-445 (2015). doi: 10.1093/ijpor/edv003

17. Gibson, R., \& Cantijoch, M.: Conceptualizing and measuring participation in the age of the internet: Is online political engagement really different to offline?. The Journal of Politics, 75(3), 701-716 (2013). doi: 10.1017/s0022381613000431

18. Horsburgh, S., Goldfinch, S., \& Gauld, R.: Is public trust in government associated with trust in e-government?. Social Science Computer Review, 29(2), 232-241 (2011). doi: $10.1177 / 0894439310368130$

19. Irani, Z., et. al. An analysis of methodologies utilised in e-government research: A user satisfaction perspective. Journal of Enterprise Information Management, 25(3), 298-313 (2012). doi: 10.1108/17410391211224417

20. Kassim, E. S., Jailani, S. F. A. K., Hairuddin, H., \& Zamzuri, N. H.: Information system acceptance and user satisfaction: The mediating role of trust. In: Procedia-Social and Behavioral Sciences, 57, 412-418 (2012).

21. Kim, S., \& Lee, J.: E-participation, transparency, and trust in local government. Public Administration Review, 72(6), 819-828 (2012). doi: 10.1111/j.1540-6210.2012.02593.x

22. Lee, A., \& Levy, Y.: The effect of information quality on trust in e-government systems' transformation. Transforming Government: People, Process and Policy, 8(1), 76-100 (2014). doi: 10.1108/TG-10-2012-0011

23. Lee, J., \& Kim, S.: Active citizen e-participation in local governance: do individual social capital and e-participation management matter?. In: 2014 47th Hawaii International Conference on System Sciences, pp. 2044-2053, IEEE (2014). doi: 10.1109/HICSS.2014.259

24. Liu, Y., \& Zhou, C.: A citizen trust model for e-government. In: 2010 IEEE International Conference on Software Engineering and Service Sciences, pp. 751-754, IEEE (2010). doi: 10.1109/ICSESS.2010.5552260

25. Ma, L.: How does E-government usage affect citizen trust: The mediating effects of government transparency and responsiveness. Journal of Public Administration, 9(6), 44-63 (2016).

26. Mahmood, M., Osmani, M., \& Sivarajah, U.: The role of trust in e-government adoption: A systematic literature review. In: Americas Conference on Information Systems, Savannah, pp. 1-16 (2014).

27. Mpinganjira, M.: Use of e-government services: the role of trust. International Journal of Emerging Markets. 10(4), pp.622-633 (2015). doi: 10.1108/JJoEM-12-2013-0151

28. Papadopoulou, P., Nikolaidou, M., \& Martakos, D.: What is trust in e-government? A proposed typology. In: 2010 43rd Hawaii International Conference on System Sciences, pp. 110, IEEE (2010). doi: 10.1109/HICSS.2010.491 
29. Porumbescu, G. A.: Placing the effect? Gleaning insights into the relationship between citizens' use of e-government and trust in government. Public Management Review, 18(10), 1504-1535 (2016). doi: 10.1080/14719037.2015.1122827

30. Sambasivan, M., Patrick Wemyss, G., \& Che Rose, R.: User acceptance of a G2B system: A case of electronic procurement system in Malaysia. Internet Research, 20(2), 169-187 (2010). doi: 10.1108/10662241011032236

31. Santamaría-Philco, A., \& Wimmer, M. A.: Trust in e-participation: an empirical research on the influencing factors. In: Proceedings of the 19th Annual International Conference on Digital Government Research: Governance in the Data Age, no. 64, ACM (2018). doi: 10.1145/3209281.3209286

32. Sasaki, F.: Online Political Efficacy (OPE) as a Reliable Survey Measure of Political Empowerment When Using the Internet. Policy \& Internet, 8(2), 197-214 (2016). doi: 10.1002/poi3.114

33. Scherer, S., \& Wimmer, M. A.: Trust in e-participation: Literature review and emerging research needs. In: Proceedings of the 8th International Conference on Theory and Practice of Electronic Governance, ICEGOV, pp. 61-70, ACM (2014). doi: $10.1145 / 2691195.2691237$

34. Scherer, S., \& Wimmer, M. A.: Conceptualising trust in E-participation contexts. In: International Conference on Electronic Participation, pp. 64-77, Springer, Berlin, Heidelberg (2014). doi: 10.1007/978-3-662-44914-1_6

35. Song, C., \& Lee, J.: Citizens' use of social media in government, perceived transparency, and trust in government. Public Performance \& Management Review, 39(2), 430-453 (2016). doi: 10.1080/15309576.2015.1108798

36. Tolbert, C. J., \& Mossberger, K.: The effects of e-government on trust and confidence in government. Public administration review, 66(3), 354-369 (2006). doi: 10.1111/j.15406210.2006.00594.x

37. Van de Walle, S., Zeibote, Z., Stacenko, S., Muravska, T., \& Migchelbrink, K.: Explaining non-adoption of electronic government services by citizens: A study among non-users of public e-services in Latvia. Information Polity, (Preprint), 1-11 (2018).

38. Van Eck, N., \& Waltman, L.: Software survey: VOSviewer, a computer program for bibliometric mapping. Scientometrics, 84(2), 523-538 (2009). doi: 10.1007/s11192-009-0146-3

39. Vidiasova, L., \& Tensina, I.: E-Participation Social Effectiveness: Case of "Our Petersburg" Portal. In: International Conference on Electronic Governance and Open Society: Challenges in Eurasia, pp. 308-318, Springer, Cham (2018). doi: 10.1007/978-3-03013283-5_23

40. Zolotov, M. N., Oliveira, T., \& Casteleyn, S.: E-participation adoption models research in the last 17 years: a weight and meta-analytical review. Computers in Human Behavior, 81, 350-365 (2018). doi: 10.1016/j.chb.2017.12.031 